О. П. Волосовець ${ }^{1}$, О. В. Виговська ${ }^{1}$, В. В. Уліщенко ${ }^{1}$, Г. В. Бекетова ${ }^{2}$, С. П. Кривопустов ${ }^{1}$, А. Я. Кузьменко ${ }^{1}$, І. О. Логінова ${ }^{1}$, О. В. Мозирська ${ }^{1}$, О. О. Колбек ${ }^{1}$ С. Д. Салтанова ${ }^{1}$

${ }^{1}$ Національний медичний університет імені О. О. Богомольця, Київ

${ }^{2}$ Національний університет охорони здоров'я України імені П. Л. Шупика, Київ

\title{
ВОРКШОП ЯК СУЧАСНА ІННОВАЦІЙНА ТЕХНОЛОГІЯ ПІДГОТОВКИ ДИТЯЧИХ ТА СІМЕЙНИХ ЛІКАРІВ
}

\author{
O. P. Volosovets ${ }^{1}$, O. V. Vigovska1, V. V. Ulishchenko ${ }^{1}$, G. V. Beketova ${ }^{2}$, \\ S. P. Kryvopustov ${ }^{1}$, A. Ya. Kuzmenko" ${ }^{1}$ I. O. Loginova ${ }^{1}$, \\ O. V. Mozyrska ${ }^{1}$, O. O. Kolbeck ${ }^{1}$, S. D. Saltanova ${ }^{1}$ \\ ${ }^{1}$ O. Bohomolets National Medical University, Kyiv \\ ${ }^{2}$ Shupyk National Healthcare University of Ukraine, Kyiv

\section{WORKSHOP AS A MODERN INNOVATIVE TRAINING TECHNOLOGY PEDIATRIC AND FAMILY DOCTORS}

\begin{abstract}
Анотація. Виклики сьогодення та розвиток дистанційної освіти у практиці підготовки дитячих лікарів, з огляду на подальше поширення коронавірусної інфекції COVID-19, вимагають запровадження у навчальний процес сучасних ефективних навчальних технологій, наприклад, таких, як воркшоп (workshop).

Мета статті - розкрити особливості впровадження клінічного воркшопу (зокрема в дистанційному навчанні) у практику підготовки майбутніх дитячих та сімейних лікарів на старших курсах закладів вищої медичної освіти.

Для реалізації ефективної підготовки майбутніх дитячих та сімейних лікарів на кафедрі педіатрії № 2 Національного медичного університету імені О. О. Богомольця використовується така навчальна технологія, як воркшоп. За нинішньої ситуації, коли збільшується роль дистанційного навчання, вона стала дієвою складовою освітнього процесу, показавши низку переваг порівняно з іншими технологіями. Ці переваги полягають, зокрема, в суттєвому зростанні ефективності роботи, спрямованої на прищеплення студентам навичок активності, самостійності, на розвиток клінічного мислення.

Наведено приклад воркшопу за темою «Діагностика та лікування різних видів гострої серцевої недостатності у дітей».

Воркшоп є ефективною навчальною технологією оволодіння новими знаннями й уміннями, що є необхідними для формування професійної компетентності майбутніх лікарів. Воркшоп допомагає розвивати клінічне мислення, формувати вміння аргументовано підходити до визначення діагнозу та обирати оптимальну стратегію лікування конкретного пацієнта.
\end{abstract}

Ключові слова: воркшоп; професійна компетентність лікаря; клінічне мислення; педіатрія; дистанційна освіта.

Abstract. Today's challenges and the development of distance education in the practice of training pediatricians in view of the further spread of coronavirus infection COVID-19 require the introduction into the educational process of modern effective educational technologies, such as workshop.

The aim of the work - to reveal the peculiarities of the introduction of a clinical workshop (in particular in distance learning) in the practice of training future pediatric and family physicians in the senior courses of higher medical education institutions.

To implement effective training of future pediatric and family physicians at the Department of Pediatrics N 2 of O.Bohomolets National Medical University such educational technology as a workshop is used. In the current situation, when the role of distance learning is increasing, it has become an effective component of the educational process, showing a number of advantages over other technologies. These advantages are, in particular, a significant increase in the effectiveness of work aimed at instilling in students the skills of activity, independence, at the development of clinical thinking.

An example of a workshop on the topic "Diagnosis and treatment of various types of acute heart failure in children" is given.

The workshop is an effective educational technology for mastering new knowledge and skills that are necessary for the formation of professional competence of future doctors. The workshop helps to develop clinical thinking, shape the ability to take an argumentative approach to diagnosis and choose the optimal treatment strategy for a particular patient.

Key words: workshop; professional competence of a doctor; clinical thinking; pediatrics; distance education.

(ㄷ) О. П. Волосовець, О. В. Виговська, В. В. Уліщенко та ін. 
Вступ. Виклики сьогодення та стрімке переформатування університетської освіти на змішане навчання (поєднання синхронної та асинхронної взаємодії із залученням навчальних платформ для дистанційної освіти) у практиці підготовки дитячих лікарів, а також подальше поширення коронавірусної інфекції COVID-19 потребують запровадження у навчальний процес ефективних навчальних технологій, наприклад, такої, як воркшоп (workshop) [1, 2].

Згідно з освітнім глосарієм, воркшоп - це навчальний захід (нарівні із семінаром, тренінгом, курсом, стажуванням), на якому учасники отримують знання самостійно. Дослівний переклад терміна «робоча майстерня» [4].

Основні критерії воркшопу - динамічне навчальне середовище на основі дотримання послідовності навчальних мікроблоків, інтенсивної групової взаємодії всіх суб'єктів навчання, високої мотивації учасників, активізації критичного мислення, дискусійності та толерантності. Роль викладача, який організує воркшоп, зводиться до структурування матеріалу, добору завдань і запитань для поглиблення навчальної мотивації, активної самостійної діяльності студентів (у групі).

Мета статті - розкрити особливості впровадження клінічного воркшопу (зокрема в дистанційному навчанні) у практику підготовки майбутніх дитячих та сімейних лікарів на старших курсах закладів вищої медичної освіти.

Теоретична частина. Для реалізації ефективної підготовки майбутніх дитячих та сімейних лікарів на кафедрі педіатрії № 2 Національного медичного університету імені О. О. Богомольця використовується така навчальна технологія, як воркшоп. За нинішньої ситуації, коли збільшується роль дистанційного навчання, вона стала дієвою складовою освітнього процесу, показавши низку переваг порівняно з іншими технологіями. Ці переваги полягають, зокрема, в суттєвому зростанні ефективності роботи, спрямованої на прищеплення студентам навичок активності, самостійності, на розвиток клінічного мислення.

Важливою умовою педагогічного успіху у процесі проведення воркшопу є співпраця викладача й студентів, трансформація ролі ментора на фасилітатора й мотиватора. Від методичної обізнаності викладача залежить створення тієї сприятливої атмосфери, що дозволить кожному студенту - майбутньому клініцисту розкритися в колективній роботі, шукати і знаходити виважені аргументи на захист власної позиції (постановка діагнозу, призначення лікування), під час дискусії обстоювати правоту своїх суджень, а в разі усвідомлення, що докази інших є грунтовнішими, приймати правильне рішення на користь пацієнта. Оволодіння студентами грунтовними знаннями, уміннями, цінностями у сфері мистецтва лікування - основа професійної компетентності клініциста.

Воркшоп є певним індикатором набутих знань та вмінь студентів за певною навчальною темою. Вiн сприяє формуванню ціннісного контексту майбутнього клініциста - конгруентності, толерантності, правдивості, переконливості, дій на захист інтересів пацієнта. Завдання ж викладача - тактовно скеровувати дискусію, акцентувати на найдрібніших деталях, необхідних для правильного визначення діагнозу, допомагати студентам самореалізуватися через дію.

Оптимальна тривалість медичного воркшопу 3-4 год. Основні методи і прийоми - аналіз й обговорення клінічної ситуації, міні-лекція з презентацією, проблемні завдання для роботи в групах (за необхідності виконання індивідуальних та групових медичних маніпуляцій), підготовка до дискусії, клінічна дискусія, висновки й активне оцінювання (можливе самооцінювання).

Важливим, на нашу думку, є елемент дебрифінгу, коли наприкінці воркшопу у процесі дискусії одна група студентів обговорює дії другої групи стосовно невідкладної клінічної ситуації. Як висновок такий вид заняття наочно демонструє динамічний процес оволодіння знаннями й уміннями, формування ціннісних складників компетентності лікаря-клініциста, він передбачає активну участь усіх учасників заходу, надає можливість конкретизувати внесок кожного студента у розв'язання проблеми та процес пошуку аргументації.

Для ознайомлення з нашим досвідом ми наводимо приклад воркшопу за темою «Діагностика та лікування різних видів серцевої недостатності у дітей», що може бути використаним як на додипломному, так і післядипломному етапах.

План навчального воркшопу на тему «Діагностика та лікування різних видів серцевої недостатності у дітей»

Ведучий: викладач кафедри педіатрії.

Актуальність. Зростання захворюваності дитячого населення на вроджену та набуту кардіальну патологію обумовлює необхідність підготовки студен- 
тів щодо оволодіння сучасними технологіями діагностики і лікування серцевої недостатності в дітей.

Мета та кінцевий результат навчального воркшопу - опановуючи технологію діагностики й лікування серцевої недостатності в дітей, увагу студентів зосереджуємо на особливостях розвитку й перебігу клінічних випадків, наприклад, серцевої недостатності в дітей, опануванні принципів діагностики та надання медичної допомоги, здійснюємо підготовку студентів до застосування на практиці алгоритмів невідкладної допомоги.

Оснащення: комп’ютер, підключений до мережі «Інтернет». Необхідне програмне забезпечення ZOOM, MyOwnConference тощо.

Вибір форми обумовлений необхідністю забезпечення навчального процесу за спеціальністю «Дитячі хвороби та дитячі інфекційні хвороби».

Форма: поєднання «вкраплення» теоретичної вступної короткої лекції (передмови) разом із наступним аналізом та клінічним розбором різних варіантів серцевої недостатності в дітей із наданням студентам максимальної самостійності. Учасники використовують наявний досвід і набуті на попередніх курсах знання та вміння щодо оцінки стану хворої дитини з кардіальною патологією. Вони діляться ними з іншими учасниками заходу. Ведучий визначає клінічні кейси (лівошлуночкова серцева недостатність та правошлуночкова серцева недостатність), контролює процес, спрямовує діяльність на активізацію груп.

На кого спрямований: студентів 6 курсів медичних факультетів за спеціальністю «Медицина», навчальна дисципліна «Дитячі хвороби та дитячі інфекційні хвороби».

Перед воркшопом. Інформація про навчальний воркшоп (найменування, зміст, дата, час проведення) розміщується в Інтернеті за 1,5 тижня до початку навчального воркшопу та надсилається студентам на електронні адреси. Необхідно одразу інформувати майбутнього слухача про його успішну реєстрацію. Лист-нагадування надсилається напередодні.

Інформаційний лист має містити можливі ситуаційні задачі, що, на наше переконання, активізує пізнавальну активність студентів, мотивує їх до цікавої роботи у складі мікрогруп.

Загальна кількість учасників: 12.

Кількість груп: 2.

Розмір однієї групи: 6 учасників.

Підготовка інформаційного листа з порадами для учасників воркшопу:
- заходити в чат за 5-10 хв до початку;

- вказувати своє ім’я, але не нікнейм чи аватарку;

- вітати учасників воркшопу;

- не провокувати конфлікти під час заходу, бути толерантними, поважати іншу думку навіть за умови, що вона комусь не дуже подобається;

- чат використовувати тільки за призначенням.

Підготовку до навчального воркшопу необхідно почати не менш ніж за 30 хв до початку з урахуванням того, що доступ слухачів відкривається за 10 хв. Учасникам надається пояснення щодо форми постановки запитання. Найпоширеніші способи підняти руку, поставити питання по мікрофону або написати його в чаті.

Зміст/план навчального воркшопу:

1. Вступ.

2. Вступна коротка лекція, що визначає актуальність проблеми серцевої недостатності в дітей як стану, що загрожує життю (лекція з презентацією Power Point).

3. Ознайомлення слухачів із сучасними підходами до діагностики та лікування серцевої недостатності в дітей.

4. Колективне обговорення проблематики теорії прийняття рішень лікарем у критичній ситуації щодо набряку легень у дитини через лівошлуночкову недостатність.

5. Практикум у вигляді аналізу кожною групою конкретних клінічних кейсів щодо серцевої недостатності в дітей.

6. Групова дискусія.

7. Активне оцінювання учасників кожної групи за участю інших груп студентів за методом дебрифінгу.

8. Оцінювання активності студентів та аргументованості їхніх суджень під час виступу.

Конкретні техніки та вправи для різних етапів воркшопу:

- на етапі мотивації: активізація уваги студентів на актуальності проблематики воркшопу;

- на етапі мотивації: активізація студентів та визначених груп щодо актуальності і важливості проблематики вебінару;

- на етапі засвоєння теоретичних знань - практично-орієнтоване подання інформації щодо засад діагностики та лікування серцевої недостатності;

- на етапі колективного обговорення - аналіз і розбір клінічних ситуацій та принципів діагностики і лікування;

- на етапі навчання (оволодіння практичними навичками спілкування) кожна група проводить мозковий штурм стосовно свого кейсу та розроб- 
ляє спільну презентацію алгоритму вирішення даної ситуації;

- на етапі підготовки до дискусії - підтримка активності учасників та їхньої самостійності й аргументованості висновків;

- на етапі групової дискусії - інтенсивна групова взаємодія у пошуках правильного алгоритму надання невідкладної допомоги;

- на етапі активного оцінювання - дебрифінг 3 боку інших учасників Workshop.

Графік воркшопу: он-лайн вступна лекція - 30 хв, практикум із вирішенням ситуаційних завдань у декількох групах - 60 хв, підбиття підсумків - 45 хв та оцінювання - 45 хв.

Структура проведення. Основні відмінності воркшопу від заходів іншого типу - висока інтенсивність групової взаємодії, активність і самостійність учасників, актуальний досвід й особисте переживання.

Вид освітнього процесу: участь у навчальному воркшопі.

Форма освіти або підвищення кваліфікації: очна та дистанційна очна.

Вартість надання освітньої послуги: участь безкоштовна.

Напрям - розвиток професійних та особистісних компетентностей майбутнього дитячого або сімей-

\section{Список літератури}

1. Дистанційне навчання як інформаційно-комунікативна технологія додипломної підготовки лікарів 3 педіатрії в умовах сучасних викликів / О. П. Волосовець, О. В. Виговська, С. П. Кривопустов [та ін.] // Медична освіта. - 2020. - № 3. - С. 9-12.

2. Про затвердження Положення про дистанційне навчання Національного медичного університету імені

\section{References}

1. Volosovets, O.P., Vyhovska, O.V., Kryvopustov, S.P., Kuzmenko, A.Ya., Loginova, I.O., Cherny, O.F., ... Kovtun, O.V. (2020). Dystantsiyne navchannya yak informatsiyno-komunikatyvna tekhnolohiya dodyplomnoyi pidhotovky likariv z pediatriyi $\mathrm{v}$ umovakh suchasnykh vyklykiv [Distance learning as an information and communication technology for undergraduate training of pediatricians in today's challenges]. Medychna osvita - Medical Education, 3, 9-12 [in Ukrainian]. ного лікаря щодо діагностики та лікування серцевої недостатності в дітей.

Набуті компетенції:

- знання й уміння сучасних технологій діагностики та лікування серцевої недостатності в дітей;

- навички щодо прийняття у невідкладній ситуації (набряк легень) рішучих й обгрунтованих рішень;

- цінності: толерантність, конгруентність, повага і робота на користь пацієнта.

Тривалість воркшопу: 4 год - кредит ЄКТС: 0,13.

Після воркшопу. Після завершення воркшопу надсилаємо його учасникам електронні листи із вдячністю за співпрацю та проявлену активність. У цьому ж листі надаємо слухачам посилання на джерела, що використовувалися під час презентації.

Висновки. Воркшоп $є$ ефективною навчальною технологією оволодіння новими знаннями й уміннями, що є необхідними для формування професійної компетентності майбутніх лікарів. Воркшоп допомагає розвивати клінічне мислення, формувати вміння аргументовано підходити до визначення діагнозу та обирати оптимальну стратегію лікування конкретного пацієнта.

О. О. Богомольця : наказ НМУ від 18 берез. 2020 р. № 160 .

3. http://osvita.ua/vnz/add-education/glossary/7701/.

4. Naidu S. Building resilience in education systems postCOVID-19 / Som Naidu // Distance Education. - 2021. - Vol. 42, Issue 1. - P. 1-4. DOI 10.1080/01587919.2021.1885092.

2. Nakaz NMU Pro zatverdzhennya Polozhennya pro dystantsiyne navchannya Natsionalnoho medychnoho universytetu imeni O.O. Bohomoltsya vid 18.03.2020 № 160 [Order of NMU Regulations on distance learning of the Bohomolets National Medical University dated 18.03.2020 No. 160] [in Ukrainian].

3. http://osvita.ua/vnz/add-education/glossary/7701/.

4. Naidu, S. (2021). Building resilience in education systems postCOVID-19. Distance Education, 42(1), 1-4. DOI 10.1080/01587919.2021.1885092.

Отримано 24.03.21

Рекомендовано 30.03.21 